\title{
The (un)receptive experiences of female rape victims who seek healthcare services*
}

Vivência de (des)acolhimento por mulheres vítimas de estupro que buscam os serviços de saúde Vivencia de (des)acogimiento por mujeres víctimas de estupro que buscan los servicios de salud

Luciana de Amorim Barros ${ }^{1}$, Maria Cicera dos Santos de Albuquerque ${ }^{2}$, Nadirlene Pereira Gomes ${ }^{3}$, Jorge Luís de Souza Riscado $^{4}$, Bárbara Régia Oliveira de Araújo ${ }^{1}$, Júlia Renata Fernandes de Magalhães ${ }^{5}$

* Extracted from the dissertation "Vivência de (des)acolhimento por mulheres vítimas de estupro que buscam os serviços de saúde," Post-graduation program in Nursing, Universidade Federal de Alagoas, 2013.

${ }^{1}$ Master's student, Post-graduation program in Nursing, Universidade Federal de Alagoas, Maceió, AL, Brasil.

${ }^{2}$ Associate Professor, Universidade Federal de Alagoas, Maceió, AL, Brasil.

${ }^{3}$ Adjunct Professor, School of Nursing, Universidade Federal da Bahia, Salvado, BA, Brasil.

${ }^{4}$ Associate Professor, Universidade Federal de Alagoas, Maceió, AL, Brasil.

${ }^{5}$ Master'sstudent, Post-graduation program in Nursing, Universidade Federal da Bahia, Salvador, BA, Brasil.

\section{ABSTRACT}

Objective: To know the structure and functioning of healthcare services from the perspective of women who have suffered rape. Method: A qualitative study conducted with 11 women who experienced rape, monitored in a maternity in the state of Alagoas, Brazil. Data were systematically based on content analysis. Results: It allowed for understanding the path taken by women in search of support from health services, as well as the limitations and capabilities of these services. Conclusion: The assistance received in healthcare services leans towards a revictimization process of women who already carry trauma from the rape. It is necessary to reflect about care practices aimed at sexually victimized women.

\section{DESCRIPTORS}

Sexual Violence; Violence Against Women; Rape; Health Services; User Embracement.
Correspondence Addressed to:

Júlia Renata Fernandes de Magalhães

Escola de Enfermagem, Universidade Federal

da Bahia

Rua Basílio da Gama, S/N - Campus

Universitário, Bairro Canela

CEP 40110-060 - Salvador, BA, Brasil

julinha_cte@hotmail.com 


\section{INTRODUCTION}

Violence against women is a major public health problem, which signals the importance of professionals perceiving this offense as a health objective. With regard to sexual violence in 2011, over 13 thousand women were attended to in the SUS, especially rape ${ }^{(1)}$.

The reference maternity hospital to care for sexually violated women in the state of Alagoas, Brazil, recorded 91 patients of sexual violence in 2013. However, this number does not represent the reality of cases in the state; in 2012, 458 rape cases were recorded by the police ${ }^{(2)}$. These numbers show that although the Maternity Hospital is a reference service, it only receives an average of $20 \%$ of the rape cases that are reported in the state. If the estimate is considered that less than $20 \%$ of these crimes come to the attention of the police ${ }^{(3)}$, it is clear that the statistics in the health, legal and police sectors do not express the total number of cases, revealing the underreporting of rape in Brazil.

Misinformation about the need for disease prevention contributes to women first seeking police stations and/or the Medical Legal Institute (IML) ${ }^{(4)}$ after suffering rape. Therefore, the search for services that are not part of the healthcare leaves them vulnerable to other problems, such as STD infection and post-traumatic stres( ${ }^{(5)}$. The complete care for women requires coordination between services. In the health scenario, it is important that this is not restricted to technical knowledge, but ensures the principles of comforting/welcoming patients ${ }^{(6)}$.

Welcoming approaches are gaining strength and discussion space in recent years, especially after the launch of the National Humanization Policy (PNH). However, there are still few studies correlating rape with reception approaches. Research in the Virtual Library database in Health (BVSBIREME) in 2011 found only 28 studies using rape and women as key-words. Cross-referencing the key-words rape and reception approaches, the search result shows only one study. Studies on welcoming approaches are needed to better qualify healthcare services for sexually violated women.

Considering the lack of research on this subject, a study was proposed to listen to women as they understand the structure and functioning of reference health assistance services for rape victims. With this in mind, the following question emerged: How was the experience of rape victims (women) who sought assistance in reference healthcare services? Given the above, we delimited the aim of the study; knowing the structure and functioning of health services from the reported perspective of women who had suffered rape.

\section{METHOD}

This is a qualitative study with 11 women who experienced rape and were treated at the outpatient clinic of a reference maternity hospital for women in situations of sexual violence in the state of Alagoas, Brazil.

The following inclusion criteria were followed: being assisted at the maternity hospital as a result of a rape experience; and being over 18 years of age. The only exclusion criterion was the recommendation from the psychologist unit not to participate, after evaluation of the emotional state of women. The number of subjects was defined using the criteria of completeness, representativeness and relevance.

This study was examined and approved by the CEP/ UFAL under N. 16313413.9.0000.5013 and obeyed the ethical principles adopted by Resolution 466/2012, in line with principles of autonomy, beneficence, non-maleficence and justice. It was made clear that participation was voluntary, and that the women could give up at any stage of the study, with no consequences to their care services. Victims' right to privacy and confidentiality of information was respected by having them identified by fictitious names. None of the women invited to participate in the study refused, so all signed the informed consent form.

Individual interviews took place at the maternity hospital clinic ward and had guidelines containing questions related to the structure and care received at the health service. Such questions allowed the women to speak freely, and at the same time directed the interview to different aspects of their experience in the reception of health services.

All interviews were recorded with the consent of women and transcribed, with the support of Microsoft Word. The mean duration was approximately 30 minutes, ranging from 20 minutes to 1 hour and 20 minutes. Data were collected between July and November 2013.

Content Analysis was used for the systematization and analysis of the interviews, which consists of discovering the units of meaning that make up a communication. After a brief primary reading of the material for the formation of the corpus, followed by the organization of documents, the criteria of completeness, representativeness, consistency, relevance and uniqueness were considered in order to grasp the central meaning of the concept, from which coding categories emerged.

Next, exploration of the material through a comprehensive analysis of testimonies for the design of sense units was performed, identified from the organization of the terms or significant words by similarity of content ${ }^{(7)}$. This step essentially consists of a classificatory operation, which allowed for empirical categories to emerge.

Finally, the data were interpreted and supported taking as a guideline the reception of the victims, based on the following theoretical and conceptual framework: it is understood as the reception of related technology, being a light technology, significant in the health work process, which is expressed as one of the guidelines of major ethical, aesthetic and political relevance of $\mathrm{PNH}$; ethics in relation to the commitment to the recognition of the other; aesthetic because it brings strategies to the relationship and daily encounters that contribute to the dignity of life; and political because it implies a collective commitment, enhancing protagonism. In this sense, dialogue with the findings was carried out from the perception of reception, while "to welcome, consent, accept, listen, give credit to, warm, meet, greet”(5).

\section{RESULTS}

The study allows us to understand the path taken by women in search of support from health services, as well 
as the limitations and potential of these to elucidate the following categories:

\section{THE PATH TRAVELED IN SEARCH OF SUPPORT FROM HEALTH SERVICES}

The statements revealed that maternity ward and the hospital-school of the city are references for cases of sexual violence, and the maternity ward is the gateway and responsible for forwarding patients to the hospital and outpatient service.

Of the 11 women interviewed, seven reached the maternity ward on the same day on which the rape occurred, and four of them attended the next day. In maternity, these women receive multidisciplinary care and prophylactic medications for non-viral STDs and contraception, vaccine and immunoglobulin for Hepatitis B, and perform laboratory tests. They are then sent to the hospital, where they receive antiretroviral chemoprophylaxis. Such procedure is confirmed in the statements:

The social worker (at the maternity hospital) was of great support. She was calling the ambulance driver all the time to take us to the hospital (Rose).

\section{(...) In the maternity clinic they asked: Are you driving? We can take you to the hospital by am- bulance (Violet).}

One of the interviewees, however, regretted not having received any guidance at the Maternity Emergency Unit:

\section{(...) We got a call saying that she forgot to get me to take the antiretroviral before sending us to the hospital. We went there but when we got there, we didn't have the referral and we had to go back again to maternity clinic (Iris).}

The reports indicate that the first consultation at the clinic is scheduled immediately, in the same week of the emergency appointment:

(...) When they saw my case, they said "you are already scheduled for today" (...) they said I would be accompanied for six months (Violet).

(...) The social worker (at the maternity clinic) said "You will be accompanied by the clinic for about a year, where you will have psychological support and gynecologist support (...) They booked me for the next Thursday (Daisy).

It is clear that although the outpatient follow-up is scheduled for the same week, some women's return to the clinic only happens later:
(...) At the maternity ward, they did the whole process so I could come here (Hospital). They ex- plained that I had to get the exams here; and told me not to stop coming to the psychologist, social worker and gynecologist consultations. They wanted to book it for the next day, but because I live far away, I said no (Gardenia).

(...) I spent a long time without seeking care. They booked me, but I did not go to the clinic. They never called me asking why I did not attend the consultation. After five months, I tried calling the service, but I couldn't get through and I had to go to the maternity to rebook it. (...) On the day of the consultation, the psychologist was not there. They said they would call me back to book and I still have not received this phone call (Daisy).

Among the 11 interviewed women, only three received outpatient treatment within a week after the rape; five women in the second week; two in almost a month; and one sought the service four months after the rape.

\section{LIMITATIONS OF THE SERVICE ASSISTANCE TO FEMALE VICTIMS OF SEXUAL VIOLENCE}

The women interviewed revealed the limitations of health services related to insufficient human resources, professional qualification, delays in care, and inadequate physical structure.

The study showed that the female rape victims interviewed in seeking care in maternity clinic had to share professional attention with pregnant women who are also waiting on obstetric emergencies. In order to illustrate these considerations, the lines of excerpts were transcribed:

\section{(...) It is a service for pregnant woman and for us (Lilac).}

\section{I think there should be more doctors in public hospitals. It was full of people, many pregnant women in the hallways (...) there were four pregnant women moaning in pain (...) it was a big confusion (Violet).}

In this context, women complained about the time of service in the health spaces. In some cases, this lengthy service generated fatigue and pain:

I came to maternity clinic at midnight. I was only seen at about 5 o'clock in the morning. I left the maternity at about 8 am. (...) All this is time consuming (Sunflower).

When we finished at the maternity it was already midnight (...) it took longer still in the hospital. (...) We were already very tired. In a lot of pain, all day! (Rosa).

In addition to the delays in service, the study indicates the need for professional training for the treatment of women in situations of sexual violence:

\section{(...) It is a subject for which no one knows what to say; no one knows what to do. (...) the doctor (of the countryside hospital) did not even look at my face (Gardenia). \\ (...) The chair was not very comfortable, but it was somewhere to sit (Sunflower).}

In addition, the interviewees considered that the ma- 
ternity structure is not suitable for the reception of women who experienced rape, regrettably, especially the lack of privacy to talk to the professional about what happened.

(...) There should be some training for these professionals. (...) My husband had to speak near another person, she heard it all. (...) She turned her face to look at me. If there was a bole I could've bidden in, I would have stuck my head there and never gotten out of it. (...) Then I went to get the documents that were in my chart and the man who assisted me mentioned it another five times: rape, rape. (...) Another woman came to assist me and she asked me "what happened to you?" I said: "I am a victim of violence." She said: "Wow! Where was it?" At the time it makes you angry (...) because she did not have to ask me that. (...) I think people who work there should have at least the sensitivity to be more discreet. (Daisy).

\section{(...) The room was an open room with a curtain, on the other side of the curtain patients were passing, nurses were passing, everybody was going back and forth (...) One person comes to say something, another comes in (...) there is no privacy. (...) It has to be in a closed room, because it is such an embarrassing situation. (...) Some- times, I wanted to say more things, but someone would walk in and I'd lose focus (Violet).}

\section{CAPABILITIES OF HeAlth SERVICES RECOGNIZED bY VICTIMIZED WOMEN}

Although the mentioned subcategories unveil barriers experienced by raped women who search for healthcare assistance, those interviewed declared they felt welcomed, protected and cared for, recognizing the capability of these services.

The welcoming (in the maternity ward) was good. (...) I was very well received. (...) the doctor [at the hospital] told me that if I had any other reaction to get back to her (Gardenia).

(...) I took the medication; I took the vaccine, I did all the tests. I felt cared for. (...) The hospital doctor was great, explaining everything. (...) He gave me a prescription and went with me to the get the medication (Violet).

(...) A very kind nurse talked to me, asked if I wanted to talk about it. I said I did not want to. She informed me of everything that would happen to me. (...) Then the doctor, the social worker, and the psychologist came. I cannot complain about the service (...) a male nurse came to give me the Benzetacil shot, I apologized and asked for a female nurse. He left right away and a female nurse came instead (Daisy).

She [the hospital's doctor] talked to calm us down: she didn't just give us an injection without talking to us. She explained about the drugs to prevent HIV. She explained that we had to keep taking the drug for a month and then undergo some tests (Azalea).

\section{DISCUSSION}

The study shows that rape victims feel welcomed by professionals of health services, and they were assisted by the multidisciplinary team consisting of doctors, nurses, psychologists and social workers. In the first consultation, they received prophylactic drugs for STDs, emergency contraception, administration of a vaccine and immunoglobulin against hepatitis B. After assessing the necessity, they are forwarded to the teaching hospital where they receive antiretroviral chemoprophylaxis. Women praised the care provided by professionals, expressed by the careful guidance of the medication and their availability to meet them in case of undesirable effects or reactions to drugs. Female victims of violence living in San José de Guaviare and Quibdo, Colombia, also realize that the attention provided by professionals is essential for them to feel cared for in health services ${ }^{(8)}$.

The welcoming of rape victims should be integrated to help clarify the use of prophylactic medications and their possible adverse effects, and to guide the patients on methods which can minimize such occurrences ${ }^{(9)}$. Endorsing such conduct, a study with women who had experienced sexual violence revealed that nurses had a welcoming attitude when attending patients ${ }^{(6)}$. In the reception, qualified listening is an essential tool for sexual violence victims being attended from the perspective of comprehensive care, since through it, it is possible that the professional has prepared responses for the identified needs while optimizing creating a connection with respect for diversity and uniqueness in the encounter between those who care and those who receive care ${ }^{(5)}$. In the case of sexual violence, effective listening presupposes receiving women with respect and solidarity, seeking ways to understand their demands and expectations.

The reception of the women who have been sexually assaulted demands safe, private and respect for diversity, since these women are vulnerable and distressed, and tend to feel embarrassed to talk about what happened to them. Professional reception of sexually assaulted women must also have the ability to demonstrate empathy, sensitivity in a non-patronizing way and listening skills ${ }^{(10)}$, situations which were not appreciated by the interviewees. Although the quality of professional-client relationship was positively evaluated, the dialogues made it clear that, based on the experience of these female victims of rape, the structure and functioning of health services within the network still have a lot to improve in order to guarantee welcoming and efficient assistance for women who are victims of violence.

The deficiency in resolving a situation can be seen from the example of Iris, who regretted not having been sent to receive antiretroviral chemoprophylaxis. She only received 
a call at her residence after five days, informing her of the nurse forgetting the medication and directing her on what to do. This mistake resulted in breach of protocol for the Ministry of Health (MS), which recommends chemoprophylaxis antiretroviral in all cases of vaginal and/or anal penetration in the first 72 hours after the violence, even if the offender's serum status is unknown ${ }^{(5)}$. In the case of Iris, we can consider that there was risk of complications.

Research conducted in São Paulo, Brazil, showed that of the total of 59 women attended, $90 \%$ started prophylaxis for HIV, but only $40.7 \%$ completed treatment and almost $80 \%$ of cases did not complete serological control and outpatient follow-up, signalling failure in assistance with regard to the continuity of follow-up for sexually victimized women ${ }^{(11)}$. The comprehensive and neutral position of the welcoming attitude in the nurse-client relationship, individualized attention, trust, empathy and establishing credibility in the professional, respect for privacy, and especially understanding of information are great allies for the improvement of adhesion ${ }^{(12)}$ between the patient and hospital administration.

With regard to the flow in reference health services, women are briefly scheduled for outpatient treatment. However, some of them only attend the service later. This fact undermines the continuity of health care for female victims of rape, hence the importance of having an active search done by the maternity service in order to avoid situations such as Daisy, who spent four months attending the clinic and in that period did not receive any connection service.

Successful experiences were highlighted in a study of post-exposure adherence to antiretroviral chemoprophylaxis in victims of sexual violence. Three interventions were identified as statistically significant to improve adherence: telephone counseling, which led the participants to read the leaflets of information on post-rape care; diaries, which are models run by support nurses and post-rape care integrated into hospital services; and follow-up visits also guided by nurses over six months ${ }^{(13)}$.

As part of the multidisciplinary team, nursing has struggled in the search for alternatives that qualify their reception practices ${ }^{(5)}$. As a strategy for the organization of the service, there is the implementation of a protocol to guide the care, facilitate the nursing process and ensure the proper recording of interventions ${ }^{(9)}$.

Another situation unveiled in the study refers to insufficient human resources. In emergency maternity care, female rape victims share the same professionals who attend to the obstetric emergencies. After all the suffering of the rape experience and the trip to arrive at the maternity ward, women still need to wait for service. A similar result was found in a study that also showed low number of professionals in relation to the demand of users ${ }^{(14)}$. Thus, in the health facilities that they are referred to, the female rape victim is subjected to long waits. The lack of specific flows for the care of women suffering violence generates a waiting time between 2 and 4 hours $^{(15)}$. In the experience of the women interviewed, this delay produces fatigue, stress and discomfort. The expression used by Rosa summarizes these difficulties: It was a long battle.

A study conducted with 54 health professionals who provide care to women victims of intimate partner violence in two states and in the north of Malaysia state that these women should be treated with sensitivity by health services, and which should seek care strategies without re-victimizing them ${ }^{(16)}$. Institutional conditions to prioritize their attendance should be created. In general, the study reveals that the wait is another situation that again exposes women. Some leave home and for about 22 continuous hours are often unaccompanied and go through a long waiting period: Waiting time during their commute, waiting in the different departments of the health service upon arrival; waiting for doctor visits.

Also noteworthy is that the environment for the care of female rape victims displays inadequate physical structure; uncomfortable furniture, a physical space without privacy since it is open room separated from other spaces by curtains. The place to receive the woman reveals itself as inappropriate, restricting dialogue with professionals, especially for leaving her more embarrassed and exposed to have to tell their story in the service. These inadequacies violate the recommendations of the MS, which calls for the service space to ensure privacy and minimize the discomfort of women ${ }^{(5)}$. Research shows that health centers and hospitals have similarities with regard to the lack of spaces reserved for reception, the delay and the absence of specific flows for the care and impersonality ${ }^{(15)}$.

Another situation that reflects the professional unpreparedness can be viewed in Daisy's account, when after informing that she came to the health service center on account of being raped, the clerk exclaimed: Wow! Where was it? This example indicates that some professionals have difficulties in their approach to these cases, often by issuing a value judgment and inappropriate language. In assistance to battered women, nurses and other health professionals should establish uncensored listening, as this is a situation where the woman feels ashamed and stigmatized. The professional must reflect and evaluate their own feelings and prejudices, in order to avoid such interference in communication with the patient ${ }^{(17)}$.

The care to female victims of rape should be based on the principle of non-judgment of women ${ }^{(10,18)}$. This is a skill that must be taught and exercised since their graduation from health courses, as improper professional posture due to personal beliefs and values can interfere with quality of care and adherence to treatment ${ }^{(12)}$. As part of academic or health education, vocational skills are a factor that interferes in the various courses of action ${ }^{(6)}$.

That unprepared professionals care for victims of rape is a reality that goes beyond the professional-user relationship, permeated by judgment and prejudice, revealing a scenario that denounces the negligence in the care of women suffering rape. Research conducted in the United States with the participation of 642 hospitals showed that less than a fifth provide comprehensive services to patients who are victims of sexual assault ${ }^{(19)}$. It is necessary for professionals to foster 
care that transcends a biological and fragmented approach, focusing only on the administration of medications.

The hegemonic medical model conceives the human body in its parts and directs the health care professional toward intervention to correct the malfunctioning of a specific mechanism ${ }^{(20)}$. In the case of rape, it is clear that the actions focus on medicine to prevent pregnancy and STDs, and not necessarily on the demands of women, especially regarding the psychological aspects. The procedures used in this type of care are still mechanistic and standardized ${ }^{(21)}$.

Research in Angola shows that the practices in the care of rape victims take on a clinical basis, prioritizing the treatment of physical injuries, without considering or contemplating insufficient subjectivity and complexity of these situations ${ }^{(22)}$. A study in the US with female victims of sexual abuse calls attention to the risk of an unwanted pregnancy, emphasizing women's vulnerability to drug abuse, psychosomatic disorders and post-traumatic stress ${ }^{(23)}$. In Sweden, of the 317 women victims of rape met, $39 \%$ had developed post-traumatic stress in the evaluation after six months, and $47 \%$ suffered from moderate or severe depression ${ }^{(24)}$.

Considering the concern for the emotional state, North American services care for victims of sexual violence using a management protocol known as Sexual Assault Nurse Examiner (SANE), designed to meet the immediate needs and prevention of sequelae. This protocol is based on comprehensive care, targeting five components: physical care; prevention of pregnancy; STD screening; psychological care; and legal care, to obtain forensic evidence ${ }^{(15)}$. Looking at psychosocial treatment, a study of 586,582 US emergency services pointed out that the psychological treatment, with the support of cognitive-behavioral therapies, allows about two thirds of women traumatized by rape to have a recovery enabling them to continue on with their lives ${ }^{(25)}$.

There are several demands related to the consequences of rape, either in the short or long term, among which are: lacerations; edema and/or foul-smelling genitals; STDs; learning difficulties in school and social relations. A North American study estimated that $15.2 \%$ of women who experienced sexual violence related to some kind of persecution during their lives, associated with feeling too afraid or believing they or someone close to them would be harmed or killed ${ }^{(26)}$. Given these consequences, reflections on the treatment of women in order to ensure health care is essential. To this end, professionals need to be trained to recognize the demands of women, not only being limited to physical treatment and prevention of unwanted pregnancy and STDs. A Women's right to mental and social health support in long term care needs to be ensured. This will certainly contribute to a better quality of life for women who have gone through the tragic experience of rape $\mathrm{e}^{(10,18)}$.

In this context, it can be said that the recognition of sexual violence as an important health and violation of human rights requires more qualification and professional services in attending to and receiving the victims ${ }^{(27)}$. It will take some management to rethink the care for victims of sexual violence in regarding logical reception that seeks to ensure a space for listening with appreciation for aspects of subjectivity, enabling to meet their demands and thus direct more comprehensive and individualized care.

\section{CONCLUSION}

Given the experience of rape, the women interviewed said they were welcomed in the health areas, especially in the care provided by doctors and nurses, and so they positively evaluated the overall service. However, the dialogues with the women pointed to inadequate maternity infrastructure mainly due to the lack of physical space to approach the woman with privacy, and there were also quantitative insufficient human resources; a situation that causes delays in care. Therefore, with regard to health areas, the study shows that health care in the health service is permeated by the delays and lack of privacy. Added to the criticism, hospital employees ended up exposing women and propagating the rape so that they were more victimized, unveiling institutional violence. This experience during the care received in health services leads to a revictimization process of these women who already carry the trauma from the rape. This reality points to institutional violence and the need for better professional preparation.

It is necessary to reflect on care practices that have been aimed at sexually victimized women, highlighting the need for better preparation of professionals working at these services and more attention not only to technical procedures, but based on humanization and the reception toward the patients/victims. This study may bring contributions to the scientific, academic, political and social fields as it provides important information for the production of knowledge on the subject and allows the redefinition of care for women in situations of sexual violence, especially rape victims.

\section{RESUMO}

Objetivo: Conhecer a estrutura e o funcionamento dos serviços de saúde a partir da fala de mulheres que vivenciaram o estupro. Método: Estudo qualitativo realizado com 11 mulheres com história de estupro, acompanhadas em uma maternidade no estado de Alagoas, Brasil. Os dados foram sistematizados com base na análise de conteúdo. Resultados: Permitiram compreender o caminho percorrido pela mulher na busca de apoio junto aos serviços de saúde, bem como as limitações e potencialidades destes. Conclusão: O atendimento recebido nos serviços de saúde favorece um processo de revitimização da mulher, que já carrega os traumas provenientes do estupro. Faz-se necessário refletir acerca das práticas de cuidado direcionadas às mulheres vitimadas sexualmente.

\section{DESCRITORES}

Violência Sexual; Violência contra a Mulher; Estupro; Serviços de Saúde; Acolhimento. 
RESUMEN

Objetivo: Conocer la estructura y el funcionamiento de los servicios de salud a partir del relato de mujeres que sufrieron estupro. Método: Estudio cualitativo realizado con 11 mujeres con historia de estupro, acompañadas en una maternidad del Estado de Alagoas, Brasil. Los datos fueron sistematizados con base en el análisis de contenido. Resultados: Permitieron comprender el camino recorrido por la mujer en la búsqueda de apoyo junto a los servicios de salud, así como las limitaciones y potencialidades de esos. Conclusión: La atención recibida en los servicios de salud favorece un proceso de revictimización de la mujer, quien ya carga los traumas provenientes del estupro. Es necesario hacer una reflexión acerca de las prácticas de cuidado dirigidas a las mujeres victimadas sexualmente.

\section{DESCRIPTORES}

Violencia Sexual; Violencia contra la Mujer; Violación; Servicios de Salud; Acogimiento.

\section{REFERENCES}

1. Waiselfisz JJ. Mapa da violência 2012. Atualização: homicídio de mulheres no Brasil [Internet]. Rio de Janeiro: Centro de Estudos LatinoAmericanos - Cebela; 2012 [citado 2014 jan. 8]. Disponível em: http://www.mapadaviolencia.org.br/pdf2012/MapaViolencia2012_atual_mulheres.pdf

2. Fórum Brasileiro de Segurança Pública. Anuário Brasileiro de Segurança Pública. São Paulo; 2013.

3. Heise L, Ellsberg M, Gottmoeller M. A global overview of gender-based violence. Int J Gynecol Obstet. 2002;78 Suppl 1:5-4.

4. Madi SRC, Knob LF, Lorencetti J, Marcon NO, Madi JM. Violência sexual: experiência do Programa de Atendimento às Vítimas de Violência Sexual (PRAVIVIS), do Hospital Geral de Caxias do Sul, RS, Brasil. Rev AMRIGS. 2010;54(1):13-8.

5. Brasil. Ministério da Saúde; Secretaria de Atenção à Saúde, Núcleo Técnico da Política Nacional de Humanização. Acolhimento nas práticas de produção de saúde [Internet]. Brasília; 2010. [citado 2013 nov. 18]. Disponível em: http://bvsms.saude.gov.br/bvs/publicacoes/ acolhimento_praticas_producao_saude.pdf

6. Reis MJ, Lopes MHBM, Higa R, Turato ER, Chvatal VLS, Bedone AJ. Experiences of nurses in health care for female victims of sexual violence. Rev Saúde Pública [Internet]. 2010 [cited 2014 Sep 7];44(2):325-31. Available from: http://www.scielo.br/pdf/rsp/v44n2/en_13.pdf

7. Minayo MCS. O desafio do conhecimento: pesquisa qualitativa em saúde. 12a ed. São Paulo: Hucitec; 2010.

8. Wirtz AL, Pham K, Glass N, Loochkartt S, Kidane T, Cuspoca D, et al. Gender-based violence in conflict and displacement: qualitative findings from displaced women in Colombia. Confl Health [Internet]. 2014 [cited July 11];8:10. Available from: http://www.ncbi.nlm.nih. gov/pmc/articles/PMC4115473/

9. Higa R, Mondaca ADCA, Reis MJ, Lopes MHBM. Atendimento à mulher vítima de violência sexual: protocolo de assistência de Enfermagem. Rev Esc Enferm USP. 2008;42(2):377-82.

10. Cybulska B. Immediate medical care after sexual assault. Best Pract Res Clin Obstet Gynaecol. 2013;27(1):141-9.

11. Ramos CRA, Medicci VPG, Puccia MIR. Mulheres vitimadas sexualmente: perfil sociodemográfico e análise do atendimento em um centro de referência. Rev Inst Ciênc Saúde [Internet]. 2009 [citado 2013 Apr 9];27(1):22-7. Disponível em: http://files.bvs.br/upload/S/0104-1894/2009/v27n1/a004.pdf

12. Reis MJ, Lopes MHBM, Higa R, Bedone AJ. Nursing care of women who suffered sexual violence. Rev Latino Am Enfermagem [Internet]. 2010 [cited 2014 Oct 25]; 18(4):740-7. Available from: http://www.scielo.br/pdf/rlae/v18n4/12.pdf

13. Chacko L, Ford N, Sbaiti, Siddiqui R. Adherence to HIV post-exposure prophylaxis in victims of sexual assault: a systematic review and meta-analysis. Sex Transm Infect. 2012;88(5):335-41.

14. Lima HS, Silva ATMC, Souza JA, Almeida LR, Lucena RP, Lucena KDT. Analysis of professional practices in health care for women in situation of Sexual violence. J Nurs UFPE Online [Internet]. 2013 [cited 2014 Mar 22];7(spe):6964-72. Available from: http://www.revista. ufpe.br/revistaenfermagem/index.php/revista/article/view/5127/pdf_4207

15. Villela WV, Vianna LAC, Lima LFP, Sala DCP, Vieira TF, Vieira ML, et al. Ambiguidades e contradições no atendimento de mulheres que sofrem violência. Saúde Soc. 2011;20(1):113-23.

16. Colombini M, Mayhew S, Ali SH, Shuib R, Watts C. "I feel it is not enough..." health providers' perspectives on services for victims of intimate partner violence in Malaysia. BMC Health Serv Res [Internet]. 2013 [cited 2014 Feb 22];13:65. Available from: http://www.ncbi. nlm.nih.gov/pmc/articles/PMC3582493/

17. Jong LC, Sadala MLA, Tanaka ACD. Forfeiting the denunciation of the aggressor: reports of female victims of domestic violence. Rev Esc Enferm USP [Internet]. 2008 [cited 2014 Sep 7];42(4):744-51. Available from: http://www.scielo.br/pdf/reeusp/v42n4/en_v42n4a17.pdf

18. Abrahams N, Devries K, Watts C, Pallitto C, Petzold M, Shamu S, et al. Worldwide prevalence of non-partner sexual violence: a systematic review. Lancet. 2014; 383(9929):1648-54.

19. Patela A, Roston A, Tilmon S, Stern L, Roston A, Patel D, et al. Assessing the extent of provision of comprehensive medical care management for female sexual assault patients in US hospital emergency departments. Int J Gynecol Obstet. 2013;123(1): 24-8.

20. Libreros Piñeros L. El proceso salud enfermedad y la transdisciplinariedad. Rev Cub Salud Pública [Internet]. 2012 [citado 2014 set. 7];38(4):622-8. Disponible en: http://scielo.sld.cu/pdf/rcsp/v38n4/spu13412.pdf

21. Moreno Preciado M. Nuevos enfoques en el cuidado del "otro". Index Enferm. 2010; 19(2-3):167-71.

22. Nascimento EFGA do, Ribeiro AP, Souza ER de. Perceptions and practices of Angolan health care professionals concerning intimate partner violence against women. Cad Saúde Pública [Internet]. 2014 [cited 2014 Oct 25];30(6):1229-38. Available from: http://www.scielo.br/ pdf/csp/v30n6/0102-311X-csp-30-6-1229.pdf

23. Munro ML, Rietz MF, Seng JS. Comprehensive care and pregnancy: the unmet care needs of pregnant women with a history of rape. Issues Ment Health Nurs. 2012; 33(12):882-96. 
24. Tiihonen MA, Bäckström T, Söndergaard HP, Helström L. Identifying risk factors for ptsd in women seeking medical help after rape. PLoS One [Internet]. 2014 [cited 2014 Oct 23];239(10):e111136. Available from: http://www.ncbi.nlm.nih.gov/pubmed/25340763

25. Miller L. Serial killers: I Subtypes, patterns, and motives. Aggress Violent Behav. [Internet]. 2014 [cited 2014 Oct 23];19(1):1-11. Available from: http://www.sciencedirect.com/science/article/pii/S1359178913001183

26. Breiding MJ, Smith SG, Basile KC, Walters ML, Chen J, Merrick MT. Prevalence and characteristics of sexual violence, stalking, and intimate partner violence victimization - national intimate partner and sexual violence survey, United States, 2011. MMWR Surveill Summ. 2014;63(8):1-18.

27. Labronici LM, Fegadoli D, Correa MEC. The meaning of sexual abuse in the manifestation of corporeity: a phenomenological study. Rev Esc Enferm USP [Internet]. 2010 [cited 2014 Sep 7];44(2):401-6. Available from: http://www.scielo.br/pdf/reeusp/v44n2/en_23.pdf 